\section{O Discurso}

\section{e a Noticia:}

\section{manuscritos}

sobre a revolta de

1720 atribuídos a

Pedro Miguel de Almeida, $3^{\circ}$ conde de Assumar

\author{
Márcia Almada [*] \\ Rodrigo Bentes Monteiro [**]
}

[*] Escola de Belas Artes e Programa de Pós-Graduação em História da Universidade Federal de Minas Gerais (UFMG) - Belo Horizonte (MG) - Brasil. E-mail:marcia.almada@gmail.com

Orcid: http://orcid.org/0000-0002-9046-9229

[**] Instituto de História da Universidade Federal Fluminense (UFF) - Niterói (RJ) - Brasil. E-mail: rbentesmonteiro@gmail.com

Orcid: http://orcid.org/0000-0002-6499-9912
Resumo: Os exames material, visual e textual de documentos postos em comparação podem esclarecer a produção e os destinos de manuscritos sobre a revolta de Vila Rica atribuídos a Pedro Miguel de Almeida Portugal, $\mathbf{3}^{\circ}$ conde de Assumar: os códices Discurso historico, e político sobre a soblevação que nas Minas houve no anno de 1720, depositado no Arquivo Público Mineiro, em Belo Horizonte (APM), e Noticia da sublevação que nas minas do Ouro Preto houve no anno de 1720, do acervo do Instituto de Estudos Brasileiros da Universidade de São Paulo (IEB-USP). O artigo realiza um balanço historiográfico acerca dos objetos de pesquisa com atenção aos primeiros tempos de suas divulgações, contextualiza as tipologias de seus textos e expõe resultados de análises em torno da materialidade dos códices.

Palavras-chave: Manuscritos; Revolta de Vila Rica; Pedro Miguel de Almeida Portugal.

\section{The Discurso and the Noticia: manuscripts on the revolt of 1720 attributed to Pedro Miguel de Almeida, 3rd Earl of Assumar}

Abstract: The material, visual and textual examinations of documents placed in comparison may clarify the production and destiny of manuscripts on the revolt of Vila Rica attributed to Pedro Miguel de Almeida Portugal, 3rd Count of Assumar: the codices Discurso historico, e politico sobre a soblevação que nas Minas houve no anno de 1720, deposited in the Arquivo Público Mineiro, in Belo Horizonte (APM), and Noticia da sublevação que nas minas do Ouro Preto houve no anno de 1720, from the collection of the Instituto de Estudos Brasileiros of the Universidade de São Paulo (IEB-USP). The article carries out a historiographic balance on the objects of research - aiming to the early times of its disclosures contextualizes the typologies of their texts, and exposes results of analyses around their materiality.

Keywords: Manuscripts; Revolt of Vila Rica; Pedro Miguel de Almeida Portugal. 
A sedição de Vila Rica foi um grave conflito ocorrido nas Minas nas primeiras décadas do século XVIII, e se voltou sobretudo contra as casas de fundição a serem instaladas a mando da monarquia portuguesa para melhor "quintar" o ouro. Alguns potentados e homens do governo - entre eles o mestre de campo e minerador Pascoal da Silva Guimarães, o ex-ouvidor Manoel Mosqueira da Rosa e o sargento-mor Sebastião da Veiga Cabral - intimidavam o governador da capitania de São Paulo e Minas do Ouro, o jovem conde de Assumar, Pedro Miguel de Almeida Portugal, e o ouvidor da comarca de Ouro Preto, promovendo arruaças de mascarados. Acuado em seu palácio na Vila do Carmo, sem apoio dos principais homens, o "conde general" — assim chamado por ter se distinguido na Guerra de Sucessão da Espanha - aceitou as quinze reivindicações dos revoltosos, perdoou o movimento e afastou o ouvidor. Ele, no entanto, passou a ser pressionado para deixar o governo.

Valendo-se de um espia, ele tomou providências para reprimir o terceiro motim que já enfrentava nas Minas. Mandou montar a tropa dos dragões, fechar o caminho e prender os rebeldes, levando-os para Vila do Carmo, Rio de Janeiro ou Lisboa. Em julho de 1720, entrou em Vila Rica com os principais homens da vila vizinha, os dragões e 1,5 mil escravos armados. Ordenou incendiar as casas de Pascoal da Silva no morro do Ouro Podre, bem como enforcar e esquartejar, sem julgamento formal, o tropeiro reinol Felipe dos Santos Freire (Fonseca, 2007; Anastasia, 2013).

\section{Fontes de dúvidas}

O introito acima foi construído com base em fontes primárias, como três longas cartas de Pedro Miguel de Almeida dirigidas a d. João V (1707-1750), nas quais se narraram o motim, sua repressão, e justificou-se o castigo aplicado sem jurisdição pertinente — ou seja, sem montar uma junta de justiça com magistrados locais. As missivas de 3 e 21 de julho e de 20 de agosto de 1720, além do termo com as condições dos rebeldes entregue ao governador em Vila do Carmo, foram transcritos do livro da secretaria do governo de Minas, em Ouro Preto, por José Vieira Couto de Magalhães. O militar e folclorista ingressou, assim, em 1862, no Instituto Histórico e Geográfico Brasileiro (IHGB), valendo-se de descrições e metáforas produzidas pelo jovem Assumar para relatar a revolta. Citou trechos das cartas impressas anexas ao artigo publicado, e evidenciou Felipe dos Santos como herói nacional, no mesmo ano de início da exaltação de Tiradentes (Magalhães, 1862, p. 515-564; Carvalho, 1990, p. 60).

Tempos depois, em dezembro de 1895, uma importante compra foi feita pelo governo brasileiro no leilão da livraria dos condes de Linhares em Lisboa, composta por aproximadamente 14 mil peças entre impressos e manuscritos. Os títulos adquiridos se destinavam ao Arquivo Nacional, ao Ministério das Relações Exteriores eà Biblioteca Nacional do Brasil (BNB), mas 
nove documentos foram comprados pelo estado de Minas Gerais, que então criava o Arquivo Público Mineiro (APM), sendo um deles, o Discurso historico, e político sobre a soblevação que nas Minas houve no anno de 1720: no fim do qual se expendem as razões que o excellentissimo senhor conde general teve para proceder summariamente ao castigo (AVC-17). Nesse tempo, a outrora Biblioteca Imperial tinha uma cópia manuscrita do texto principal, feita em 1825, indicando que naquele ano o códice já estava sob a guarda da casa de Linhares. ${ }^{1}$

O documento anônimo, de 479 páginas, com dimensões de metade de uma folha A4, escrito com caligrafia clara e organizada e muitas citações eruditas, foi para Ouro Preto, onde seu texto central foi transcrito pelo primeiro diretor do APM, José Pedro Xavier da Veiga, sendo publicado em 1898 no jornal Minas-Geraes e no livro A revolta de $1720 \mathrm{em}$ Vila Rica: discurso historico-político. Xavier da Veiga pondera que os dizeres transcritos, a matéria, o estilo e o tom mostram que o trabalho "é da própria lavra do conde-general (conde de Assumar), ou de alguém por ele". Qualifica, então, seu estilo como gongórico, asiático, com erudição baseada na jurisprudência coeva e na literatura clássica. ${ }^{2}$ Segundo ele, as muitas notas marginais do documento seriam parafraseadas no texto central. Por sua vez, Felipe dos Santos seria herói e mártir daquele movimento, e o livro, um "código de tirania" com muitos fatos adulterados (1898, p. 3-6). ${ }^{3}$

A edição de Xavier da Veiga foi consultada por Diogo de Vasconcelos para escrever História antiga das Minas Gerais, de 1901 e reeditada em 1904. No capítulo sobre o governo de Pedro de Almeida, após narrar conflitos com o clero regular, as iminentes casas de fundição, os motins de São Francisco, Pitangui, fugas de escravos e castigos, o historiador - que admirava o estilo romântico de Chateaubriand - encontra no drama de 1720 sua mais perfeita expressão. Conquanto por vezes não cite as fontes utilizadas, há trechos entre aspas ou parafraseados do Discurso editado e das cartas, comparados à tradição oral. Sobre a lenda da morte de Felipe dos Santos atado a quatro cavalos, Vasconcelos prefere a versão da forca seguida por esquartejamento existente no Discurso, "obra que se não é do Conde foi inegavelmente por ele revista e corrigida”. Adiante concebe o documento como uma peça de defesa, um "panfleto destinado a fazer opinião" ante o processo movido contra Pedro de Almeida em sua volta a Portugal. Qualifica seu estilo como laudatório, gongórico

' BNB, Manuscritos, 15, 2, 5, Discurso histórico e político sobre a sublevação que nas Minas Geraes houve no ano de 1720. Esse documento não apresenta notas marginais. O termo de abertura do APM de 30 de abril de 1896 sinaliza a entrada do documento número 307 (Discurso). APM, 1.3, 1, doc. 3.

${ }^{2} \mathrm{Na}$ Roma antiga, asianismo era o estilo empolado com ritmos e efeitos, classificado por Cícero em dois tipos: com frases breves e conceitos, ou mais pomposo, enfático e veloz, adornado com figuras (Citroni, 2006, p. 261). Já o religioso e letrado espanhol Luis de Góngora, expoente da literatura no Siglo de Oro, foi especialmente atento à sonoridade dos versos. As duas qualificações aqui são depreciativas e genéricas, referindo-se a uma linguagem prolixa e elaborada. ${ }^{3}$ Identificado ao IHGB, Xavier da Veiga valoriza a busca de fontes obtidas mediante uma rede de correspondentes. Nesse sentido, insere-se a criação da Revista do Arquivo Público Mineiro, em 1896. Em Efemérides mineiras (1898), a sedição de Vila Rica foi comentada em 29 páginas. No verbete de 28 de junho, o jornalista e político não menciona o códice do Discurso, provavelmente por não ter terminado sua transcrição (Veiga, 1998, v. 2, p. 597-612; Silva, 2007. p. 74-91) 
e difuso, mas compreende a missão histórica do conde nas Minas, por ter apanhado a luva e enfrentado "uma luta de centauros" (Vasconcelos, 1974, p. 172-209). ${ }^{4}$

Antecipando o bicentenário da revolta, em 28 de junho de 1919, o sócio do Instituto Histórico e Geográfico de Minas Gerais (IHGMG), Antonio Olyntho dos Santos Pires, profere uma palestra no IHGB sobre o episódio precursor da independência, com Felipe dos Santos antecedendo Tiradentes. Olyntho ressalta os documentos: as cartas do governador e "uma interessante defesa que dele fez um escritor anônimo". Cita, então, várias passagens do Discurso, valendo-se da eloquência do texto, tido por ele como gongórico, ao descrever os costumes das Minas, intercalados com referências greco-latinas. Relata a vida de Pedro Miguel de Almeida, acentuando o contraste entre sua formação militar e aquele meio rústico, e, após enaltecer Felipe dos Santos, volta a se referir ao documento editado (1921, p. 443-498).

Alberto de Moraes Lamego se tornou sócio do IHGB após uma estada europeia de catorze anos, durante a qual adquiriu muitos livros e documentos. Ao fim de 1929, publicou oito artigos numa coluna em O Jornal, no Rio de Janeiro, e no Diário de São Paulo, ambos de Assis Chateaubriand. Na primeira matéria, o advogado fluminense revelava ter um "interessante manuscrito, adquirido há anos em um alfarrabista de Lisboa". Com 58 páginas do tamanho de uma folha A4 e uma assinatura, segundo ele, "raspada", para Lamego o texto contém "tantas minudências e particularidades referentes ao conde de Assumar que atribuímos ser ele o autor", ainda mais por verificar semelhança de estilo com as cartas escritas pelo nobre português. Ignorando o códice existente no APM e sua edição, o bibliófilo considera a Noticia da sublevação que nas minas do Ouro Preto houve no anno de 1720 (IEB-USP, AL-61) "a narração mais completa [...], que embora examinada por muitos dos nossos historiógrafos, é ainda motivo de controvérsias" (Lamego, 13/10/1929, p. 4). Nesse e nos artigos seguintes, parafraseia o manuscrito, cruzando sua narrativa com outros documentos. Nesse tempo, o colecionador vivia em seu solar em Campos dos Goytacazes, lá recebendo hóspedes amigos e interlocutores, entre eles Affonso Taunay, que, em sua História geral das bandeiras paulistas, após citar o Discurso editado em 1898 - atribuindo-o ao conde de Assumar — junto a outras fontes e bibliografia, menciona Lamego como um dos que restabeleceram a verdade sobre o episódio, por ter adquirido o manuscrito da Noticia e publicado sua suma.

Segundo o historiador radicado em São Paulo, o documento seria um "relato anônimo curioso, que deve ter sido redigido por indivíduo muito informado e testemunha presencial do motim". Ele, porém, não vincula as duas narrativas, atendo-se a discutir a forma do suplício de Felipe dos Santos e criticar a versão nacionalista da revolta (Taunay, 1949, p.

\footnotetext{
${ }^{4}$ Diogo de Vasconcelos foi um dos fundadores do IHGMG, em 1907, e o primeiro a interpretar a história mineira numa visão de conjunto. Buscando fontes no APM junto ao amigo Xavier da Veiga e alhures, a ideia de História antiga surgiu no contexto da mudança da capital para a futura Belo Horizonte. Para ele, Assumar era mais próximo às famílias paulistas, enfrentando os potentados forasteiros, e a anarquia e a natureza inóspita seriam aspectos matriciais da sociedade mineira - tópica do século XVIII, inclusive no Discurso. O autor, assim, se afina com Assumar, justificando de certo modo sua violência (Romeiro e Silveira, 2014).
} 
179-180). Incentivado por Taunay, Mário de Andrade se hospedou no referido solar e, em 1935, intermediou a compra e o transporte daquele acervo para o estado de São Paulo (Soffiati, 1992). Doravante, a coleção Lamego pertenceria à Universidade de São Paulo (USP) e, desde 1968, ao Instituto de Estudos Brasileiros (IEB) dessa instituição. Outro interlocutor de Lamego era Rodolfo Garcia, editor da obra de Francisco Adolfo de Varnhagen. No tomo IV da História geral do Brasil publicada em 1934, enquanto no texto central Varnhagen discorre sobre a revolta de Vila Rica, Rodolfo Garcia comenta em nota o manuscrito da Noticia, ainda pertencente a Lamego, como sendo uma "relação bastante desenvolvida" que possuía uma assinatura riscada e ilegível, parecendo ser do conde de Assumar (Varnhagen, 1981, p. 108). ${ }^{5}$

Fundamentado no outro códice, Teófilo Feu de Carvalho contesta o protagonismo do tropeiro rebelde. No Ementario da historia mineira, o historiador que por várias vezes foi diretor do APM referencia muitas fontes em 23 capítulos sobre a sedição de Vila Rica, com críticas às imprecisões de Diogo de Vasconcelos (1974), e louva o perfil autoritário e ordeiro de Assumar em detrimento dos amotinados "portugueses" - sobretudo Felipe dos Santos, inferior ao herói brasileiro Joaquim José da Silva Xavier. Com estilo afeito a polêmicas, Carvalho esclarece episódios do movimento, e cita várias passagens do Discurso, imputando sua autoria ao jesuíta Antonio Correia, que vivia junto a José Mascarenhas no "palácio" de Pedro de Almeida (Carvalho, 1933). ${ }^{6}$

A autoria do Discurso também foi evidenciada por Gilberto Freyre em 1936, voltando-se para as transformações da sociedade patriarcal brasileira. Em seu vai e vem de exemplos entre os séculos XVIII e XIX, ao tratar da mudança dos mineiros para os sobrados, Freyre cita uma passagem do Discurso na qual o conde de Assumar "ou alguém que se supõe ter sido ele" observa aqueles homens de origem obscura que, ao enriquecerem por comércio ou mineração, enfeitam-se com títulos, imitando a nobreza territorial e militar do reino (1985, p. 278).

Com o foco em sobrado mais concreto, a morada de Pedro de Almeida em Vila do Carmo é o pivô do livro do polígrafo Salomão de Vasconcellos, quando defende a posição do tio Diogo, que situa o hoje conhecido "palácio do conde de Assumar" na ladeira de São Francisco, onde depois residiria o primeiro bispo de Mariana, frei Manoel da Cruz. Assim, Salomão rebate

\footnotetext{
${ }^{5}$ No IEB-USP, a coleção Lamego é formada por 3,75 mil impressos e mais de 4 mil manuscritos concentrados nas histórias de Brasil e Portugal, além de rica iconografia (Nogueira et al., 2002). Em artigo posterior, Garcia, então diretor da BNB, destaca a contenda sobre a execução de Felipe dos Santos, endossa a versão de Vasconcelos com base no Discurso, cita trecho do documento sem dizer se consultou a edição de 1898 ou a cópia manuscrita da BNB, mas não faz relação entre esse documento e a Noticia (Garcia, 1945, p. 134).

${ }^{6}$ Feu de Carvalho não explicita os motivos para atribuir essa autoria (1933, p. 20, 98, 125). Adriana Romeiro descobriu, pelo processo inquisitorial do padre baiano Manoel Lopes de Carvalho, que Antonio Correia tinha trechos da Clavis prophetarum, de Antonio Vieira, e elucida a entrada do milenarismo nas Minas pelo sertão após a morte de Vieira na Bahia (Romeiro, 2001, p. 139-167). A autora corrobora, assim, a existência de um profetismo na região à época, algo expresso na visão do padre Belchior Pontes sobre a revolta de Vila Rica (Fonseca, 1752, p. 242-248), nas ideias de Pedro Henequim (Gomes, 1997) e em trechos do Discurso.
} 
as opiniões que localizam a residência do famigerado governador em outro lugar. A fim de afirmar que o referido governante residia atrás da igreja de São Francisco, onde ficaram os dragões durante a revolta, o autor arrola a tradição oral e vários documentos, entre eles o Discurso (Vasconcellos, 1937, p. 48, 92, 97-98, e 1947, p. 37). ${ }^{7}$ A afinidade com aquele texto era comum na família. Em 195l, o arquiteto Sylvio de Vasconcellos, filho de Salomão, ao caracterizar a instabilidade da sociedade mineradora, vale-se do Discurso em seu primeiro livro sobre Vila Rica, ao citar uma passagem e imputar sua autoria ao conde de Assumar (Vasconcellos, 1977, p. 37-38). Em 1968, no exílio na Europa e com acesso a escritos de Pedro de Almeida pela Biblioteca Nacional de Portugal (BNP), repete a citação, doravante das mais conhecidas do documento. ${ }^{8}$

Charles Boxer referencia várias fontes no seu capítulo sobre Vila Rica em The Golden Age of Brazil, entre elas o Discurso editado em 1898, concebendo-o como a publicação integral da versão de Assumar sobre a revolta (1969, p. 185, 213 e 389). Cabem a Hélio Gravatá os únicos comentários sobre o estado físico do códice depositado no APM e valiosas referências aos artigos em jornal de Lamego, sem relacionar as duas fontes. ${ }^{9}$ Ao priorizar a bibliografia produzida no período colonial, José Honório Rodrigues acompanha o escrito de Xavier da Veiga em 1898 e resume o Discurso, por ele endossando a atribuição de sua autoria ao conde, a detração dos mineiros e o protagonismo de Pascoal da Silva na revolta. Ademais, percebe no texto uma técnica retórica à maneira dos historiadores antigos, que recriavam na narrativa os discursos pela boca dos oradores/personagens (1979, p. 343-347).

Laura de Mello e Souza inicia seu interesse pelo Discurso com a passagem citada por Sylvio de Vasconcellos. Desde seu primeiro livro sobre Minas Gerais, em 1981 (1994, p. 36-38), seguido por Desclassificados do ouro (1982, p. 106), O diabo e a Terra de Santa Cruz (1986, p. 70-71) e Inferno atlântico (1994, p. 46 e 207), ela destaca a visão de Assumar sobre a natureza infernal das Minas, que evaporam tumultos e exalam motins. A desordem social e o imaginário diabólico na América são temas próprios da primeira fase de sua obra. ${ }^{10}$ Mas, no estudo crítico feito

\footnotetext{
Em livro sobre os palácios de Vila Rica, Francisco Antonio Lopes menciona rapidamente o códice existente no APM (1955, p. 99)

8 "Os dias nunca amanhecem serenos; o ar é um nublado perpétuo; tudo é frio naquele país, menos o vício, que está ardendo sempre. Eu, contudo, reparando com mais atenção na antiga e continuada sucessão de perturbações que nela se veem, acrescento que a terra parece que evapora tumultos; a água exala motins; o ouro toca desaforos; destilam liberdade os ares; vomitam insolências as nuvens; influem desordens os astros; o clima é tumba da paz e berço da rebelião; a natureza anda inquieta consigo e, amotinada lá por dentro, é como no inferno". O ensaio Mineiridade se tornou um clássico nos estudos sobre Minas (Vasconcellos, 1968, p. 24-25).

9 Segundo Gravatá, o códice do APM apresentava 2 folhas em branco, seguidas por 238 follhas escritas e 4 em branco, não numeradas, mas indo de 1 a 30, de 8 em 8 folhas, com letra igual à do manuscrito, sendo as de 1 a 125 numeradas a tinta em números modernos. Já havia furos nas folhas, transcrições latinas nas margens e o escrito DISCVRSO HISTORICO na lombada. Sucedem-se a remissão aos comentários de Xavier da Veiga sobre a chegada do manuscrito, sua edição de 1898 - sem as notas marginais -, as referências aos artigos de Lamego e ao escrito por Taunay sobre a Noticia (1976, p. 283-286; 1998, v. 1, p. 109-117)

${ }^{10}$ Em sua tese defendida em 1983, Caio Boschi se vale da mesma passagem por Vasconcellos para citar o Discurso em nota (1986, p. 169).
} 
para reeditar o Discurso, a percepção da autora sobre o documento adquire um forte matiz político. Ante o inesperado desaparecimento do códice do APM, para o novo livro Mello e Souza utiliza a já então rara edição de 1898 e a cópia manuscrita da BNB. Comenta em nota o exemplar da coleção Lamego, percebendo seu texto sem as digressões e as referências do Discurso, atendo-se aos acontecimentos do levante, bem como sua linguagem "mais moderna", parecendo ser de meados ou da segunda metade do século XVIII. Seu estudo sobre o Discurso tem grandes méritos ao discutir a historiografia tradicional de Minas sobre a revolta — com muitos títulos aqui referidos - e vincular o documento à biografia, aos escritos e inventário da biblioteca de Pedro de Almeida, $3^{\circ}$ conde de Assumar a partir de 1733, depois $1^{\circ}$ marquês de Castelo Novo e $1^{\circ}$ marquês de Alorna (1994, p. 13-56).

O impacto dessa nova edição foi grande, nas publicações da autora e na plêiade de historiadores que passaram a interpretar o texto, sedimentando-o como um dos mais citados na história do Brasil." ${ }^{11}$ Em toda essa historiografia, todavia, salta aos olhos a desproporção de comentários sobre um e outro escrito, pois a transcrição do códice do APM e suas duas impressões o divulgaram bastante, o que não ocorreu com a Noticia. Por sua vez, o sumiço temporário do exemplar em Belo Horizonte inviabilizou a comparação entre os documentos, fazendo com que opiniões sobre o Discurso fossem formuladas e reproduzidas acriticamente. Permanecem, portanto, as dúvidas: por quem, para que, quando e onde os dois textos foram pensados e redigidos? Quais as diferenças entre eles, se ambos foram concebidos sob a égide do governador da capitania? Nem todas as questões podem ser resolvidas agora. No entanto, o reaparecimento do códice no APM, a digitalização das duas fontes e novos estudos sobre cultura escrita e análise de documentos ampliam bastante as possibilidades de pesquisa. ${ }^{12}$

\section{Notícias e discursos}

Será preciso compreender as designações dos textos, relacionando-as ao âmbito de origem. Para o padre teatino Rafael Bluteau, tutor do adolescente Pedro de Almeida (Norton, 1967, p. 15-16; Pereira, 2016, p. 80) antes de sua ida para a Guerra de Sucessão da Espanha (17011713), notícia era o próprio conhecimento ou coisa a ser conhecida, fosse evidente, fosse duvidosa. Ao resultar de opiniões e conjeturas, ela não era certa como a ciência, mas era

"A autora publicaria ainda um estudo sobre o discurso de posse de Pedro de Almeida como governador da capitania de São Paulo e Minas do Ouro (Souza, 1999, p. 30-42) e um capítulo sobre a trajetória do governante, aprofundando temas (2006, p. 185-252). Um balanço de trabalhos que lidam com o Discurso após a reedição de seu texto central em 1994 foi feito recentemente (Monteiro, 2015).

12 Trata-se de pesquisa em curso. Uma nova transcrição do códice do APM foi feita, e os trechos em latim, traduzidos para o português, considerando as cerca de 433 notas marginais omitidas nas edições de 1898 e 1994. O códice do IEB-USP também foi transcrito. 
diferente de nova, termo que divulgava um evento recente, talvez sem fundamento ou dono (Bluteau, 1728, p. 754-757; Lisboa, 1998, p. 343-344).

Após os estudos sob tutela do dicionarista e da mãe, $2^{a}$ condessa de Assumar, os oito anos vividos na Espanha foram importantes na formação do jovem Pedro de Almeida, que voltou a Portugal em 1713 como general e comandante das tropas lusas. Em Barcelona, onde residiu com o pai embaixador quando não estava em batalhas, ele conviveu com nobres, militares, letrados e artistas de vários países, conforme o perfil cosmopolita da frente aliada na ciudad condal (Marcos e Monteiro, 2017). Entre Madri e a península itálica, a cidade tinha ligações com os mercados editoriais de Lyon e Veneza, sendo um centro de circulação de ideias e produção tipográfica. Para evitar a concorrência estrangeira na venda de livros, desde meados do século XVII os impressores catalães publicavam folhetos de notícias - peças soltas de pequeno formato, com até vinte páginas, também nomeadas gazetas ou relações, com informes sobre temas políticos ou militares, de grande aceitação popular.

A maioria dos folhetos saídos dessas oficinas reproduzia o já impresso em Madri, Paris, Viena, Roma ou Amsterdã, mas na oficina de Rafael Figueró, favorecido por sua fidelidade ao arquiduque Carlos de Áustria, notícias de eventos ocorridos na capital catalã eram anexadas aos opúsculos (Pla, 2013). Esta oficina publicava ainda relações de festas pagas por autoridades locais - como os folhetos encomendados pelo $2^{\circ}$ conde de Assumar, João de Almeida Portugal, representante da monarquia portuguesa na corte austracista — ou notícias de batalhas, algumas evidenciando o nome de Pedro de Almeida. ${ }^{13}$

A Gazeta de Lisboa, único periódico impresso português após os coevos à Restauração (1640-1668), surgiu seis meses após o tratado de Utrecht, em folhetos quinzenais de oito a doze páginas. Desde o início da guerra de sucessão, folhetos "noticiosos" em português passaram a ser publicados periodicamente em Lisboa, alguns deles chamados gazetas. A Gazeta lisboeta pode ter surgido do hábito de ler notícias em português sobre batalhas europeias durante o conflito. Seu redator era José Freire Monterroio Mascarenhas, ex-combatente e

${ }^{13}$ Por exemplo, os follhetos compilados por Diogo Barbosa Machado. BNB, Obras Raras, Nvmeroso cvlto, mvsico festejo, en aplavso de las felicíssimas, y reales bodas del [...] rey de Portugal Don Juan Quinto, con la sereníssima archidvqvesa Doña Mariana de Avstria [...] por el excelentíssimo señor conde de Assvmar [...]. Barcelona: Rafael Figueró, 1709, 23, 2 , 2: Relacion de la avdiencia pvblica [...] tuvo de las majestades católicas el excelentíssimo señor conde de Assvmar [...] participandoles la noticia del real defpoforio del serenifsimo señor rey de Portugal Don Juan Quinto con la sereníssima señora reyna doña Mariana de Avstria [...]. Barcelona: Rafael Figueró, 1709, 25, 3 bis, 10; Relacion, de la forma en qve el exmo. señor conde de Assvmar [...] participò a la sra. emperatriz reyna, el nacimiento de la princesa [...] Barcelona: Rafael Figueró, s. d., 23, 1, 3; Relacion del feliz svcesso [...] señor conde de Atalaya [...]. Barcelona: Rafael Figueró, 1708, 23, 4, 6; Gazeta de Barcelona [...]. Barcelona: Rafael Figueró, 1709 e Copia de la carta, qve [...] Guido de Starhemberg, efcrivió [...] al rey nueftro señor [...] relacionando la gloriofa batalla [...] en el campo de Alcarria [...]. Barcelona: Rafael Figueró, [1710], $23,4,7$. 
próximo aos Almeidas Portugal. ${ }^{14}$ Os eventos de lugares distantes eram os preferidos para serem narrados, mas eram raras as notícias publicadas sobre o Brasil (Belo, 2001, p. 112-113).

João Luís Lisboa e André Belo concedem atenção a um tempo no qual a oralidade e o conhecimento direto dos eventos eram importantes na comunicação. Percebem, assim, os vínculos entre imprensa oficial e publicações episódicas, periódicos impressos e manuscritos, histórias orais e escritas, entendendo que eventos e notícias eram concebidos e circulavam por diferentes meios. Naquele mundo não havia dicotomia entre o oral e o escrito. Mesmo os textos que não aparentavam reproduzir o discurso oral portavam traços da leitura em voz alta, frequentemente em grupo. Um texto escrito podia ser depois escutado e lido, só escutado ou apenas lido. Não raro, os textos continham uma pontuação alusiva à dimensão oral, sendo mais confiáveis ao invocar um testemunho do que era então recontado (Lisboa, 1998, p. 32-49; Belo, 2005). ${ }^{15}$ Esses aspectos se evidenciam, no Discurso e na Noticia, pela eloquência das expressões utilizadas e pela busca de palavras adequadas na feitura de um e outro exemplar, deixando entrever um possível processo coletivo de redação entre os autores intelectuais e o gráfico.

As notícias impressas se associavam à circulação de novelas manuscritas na Europa nos séculos XVII e XVIII. Os círculos eruditos das pequenas academias provinciais e da corte, junto à monarquia portuguesa, controlavam a difusão da informação, qualificando pejorativamente o elemento popular. Entre 1715 e 1725, a Gazeta de Lisboa era impressa na mesma oficina da Academia Real da História, fundada em 1720. Seu estatuto era superior, mas seus privilégios a faziam menos interessante, pois nela não se podia dizer tudo. ${ }^{16}$ Já as notícias manuscritas eram valorizadas por testemunharem o ocorrido, serem menos custosas, com difusão rápida e menos constrangimentos, permitindo adequar seus exemplares aos destinatários. Os novelistas, entretanto, não queriam divulgar muito as notícias ou publicá-las

\footnotetext{
${ }^{14}$ De 1704 a 1710, José Freire Monterroio Mascarenhas atuou na guerra na Espanha junto a tropas inglesas. De volta ao reino, frequentou academias literárias e criou a Gazeta, conhecida por seu estilo e sua erudição. Contudo, ele vinha de um ramo ilegítimo dos Mascarenhas, herdando a cultura nobiliária, mas não os privilégios. Após a guerra, vendeu seu talento para escrever trabalhos no mercado de impressos. Traduziu e publicou dezenas de relações de sucessos, tratados de paz e manifestos políticos europeus, nos quais quase não assinou o nome. Foi autor também de manuscritos que lhe davam mais prestígio. Apesar de protegido do conde de Ericeira, não entrou para a Academia Real da História Portuguesa (Machado, 1747, p. 853-857; Belo, 2005, p. 193-200, 220 e 259).

${ }^{15}$ Ao estudar os "murmúrios" nas Minas setecentistas durante os conflitos, Tarcísio Gaspar tem o Discurso na edição de 1994 como carro-chefe do capítulo sobre a revolta de 1720. Alude à importância do aspecto oral naquela sociedade por meio do texto, que evidencia um governante atento à sua reputação, aos ditos e ouvidos de potentados e populares, que influenciavam o jogo político. Mas não analisa o documento em sua dinâmica de escrita, leitura e audição (2011, p. 83-109).

${ }^{16}$ A época, os impressos passavam pela censura dos poderes Ordinário dos bispos, da Inquisição e do Desembargo do Paço, cujas licenças eram necessárias a qualquer publicação (Martins, 2005).
} 
logo, preservando-as de modo a configurar um círculo seleto, conforme a distinção social do Antigo Regime (Lisboa, 1998, p. 397-402 e 460-464; Belo, 2005, p. 176-181). ${ }^{17}$

Monterroio se correspondia com o $4^{\circ}$ conde de Ericeira, Francisco Xavier de Menezes - acadêmico do reino ligado às reuniões savantes da corte desde o fim do século XVII que enviava notícias de Lisboa para a Gazeta antes da censura oficial -, e com dois eruditos novelistas de Santarém que coordenavam a redação de periódicos manuscritos com alguma difusão. Eles eram leitores discretos da Gazeta, e conheciam as matérias publicadas e as que circulavam por meios manuscritos ou orais, divididos entre o apreço pela conversação cortesãe a importância crescente da escrita. Assim, exemplares de notícias sobre guerras ou naufrágios eram trocados por odes medievais, registros sepulcrais, genealogias ou curiosidades antigas. As notícias escritas à mão apresentavam uma formalização textual próxima à imprensa periódica, mas com mais liberdade no tratamento de assuntos. Os eventos que exprimiam turbulências tendiam a ser ausentes do impresso, ao significarem uma desordem no corpo político. Monterroio selecionava a informação, dispondo de textos que não eram publicados - por exemplo, sobre eventos em praças do império ultramarino português (Lisboa, 1998, p. 377 e 500; Belo, 2005).

Algumas notícias eram transformadas em papéis, opúsculos de até dezenas de páginas com um discurso mais circunstanciado do que os curtos relatos da Gazeta. Dessa forma, o redator ganhava distância e tempo em relação aos acontecimentos, para triar a informação e desenvolver seu estilo sem os limites do periódico (Belo, 2005, p. 257-259). Desde o século XVI, imprimiam-se em Portugal relatos de viagens, naufrágios e cercos militares. No Setecentos, os assuntos eram diversos, mas o da guerra predominava, anexando-se também informações locais mais desenvolvidas. Dessa forma, driblava-se a censura, mais incidente na publicação periódica. Monterroio editou mais de 120 dessas brochuras entre 1708 e 1759 (Lisboa, 1998, p. 346 e 397). ${ }^{18}$ Seria esse o planejado destino da Noticia, ou ela teria sido redigida para circular em forma manuscrita?

Por sua vez, discurso seria o próprio ato de fala, de discursar, ou um termo dialético, significando um grau alcançado de entendimento pelo uso da razão, que passaria de uma proposição a outra mediante raciocínio e argumentação. Há vários exemplos de uso da

\footnotetext{
${ }^{17}$ As notícias podiam passar de um gênero literário a outro, como as memórias do $1^{\circ}$ conde de Povolide, depois publicadas, ou permanecerem manuscritas e quase secretas, na forma dos diários de João de Almeida Portugal, $2^{\circ}$ conde de Assumar (Marcos e Monteiro, 2017).

${ }^{18} \mathrm{Em}$ meados do século XVIII, os feitos lusos na India foram louvados com base no triunfo quinhentista de João de Castro (Monteiro, 2000, p. 21). Monterroio participou desse movimento com uma série de brochuras sobre Pedro de Almeida: a Epanaphora indica. Uma delas contém uma carta do marquês ao autor, na qual Ihe professa amizade, explicita a correspondência mantida, informa como fez a relação da campanha passada e pede, sobre a última, que "escolhesse aquilo que the parecesse imprimir". Sinaliza ainda que recebia as gazetas pela secretaria de Estado, não havendo necessidade de o redator remetê-las, somente "as suas boas novas". BNB, Obras Raras, 23, 4, 10, Mascarenhas, Epanaphora indica parte III. Continua-se em referir os inclitos progressos do [...] marquez de Castelo Novo vice-rey [...]. Lisboa: S. ed., 1748, p. 88-89. Nesses opúsculos não se verifica semelhança de estilo com o Discurso e a Noticia.
} 
expressão, alguns alusivos ao sentido de espaço de tempo (Bluteau, 1728, p. 245). Em suma, o termo expressa a exposição oral e/ou escrita de um exercício intelectual.

O Discurso em tela, todavia, indica sintonia com as ideias de Aristóteles, pois o estagirita representava um paradigma de compreensão da natureza, do Universo e dos homens em Portugal e suas conquistas até meados do século XVIII. O sistema aristotélico integrou a formação dos jesuítas Antonio Correia e José Mascarenhas, que estudaram e lecionaram em Olinda, Rio de Janeiro e São Paulo (Souza, 1994, p. 26), e também formou o cabedal de Bluteau e de Pedro de Almeida. Ademais, o Discurso parece distante das regras da Academia Real da História (Cunha, 2006, p. 11-47; Mota, 2003, p. 53-76), ao apresentar constantes sobreposições de referências, fontes e tempos históricos, bem como ideias escatológicas provenientes de mitologias pagãs e bíblicas ao longo do texto. Trata-se de um certo saber ocultista relacionado à "sofística sagrada" (Fumaroli, 2009, p. 257-391), que se encontra mesclado a histórias de reinos, guerras e conquistas, registros orais e escritos, e concepções sobre o mundo natural coerentes à física peripatética, ${ }^{19}$ nada tendo a ver com o intento acadêmico de separar as histórias eclesiástica e secular, no afã da comprovação documental.

No aspecto político, no entanto, o Discurso se distingue do apreço grego ao bom governo monárquico ante a degenerada tirania (Aristóteles, 2006, p. 105-126), ideias reelaboradas pela concepção de um pacto entre Deus, povo e o rei, conforme o neotomismo incidente em Portugal e no ultramar americano (Torgal, 1981-1982; Baldini, 1995; Monteiro, 2002). O texto em tela prefere tratar da literatura pragmática da arte do Estado e sua reinterpretação de autores latinos, mormente das catilinárias de Cícero e do livro de Salústio sobre a mesma conjura (Monteiro, 2015). ${ }^{20}$

Percebe-se também no documento - estereotipado outrora como gongórico ou asiático - uma metamorfose dos preceitos de matriz aristotélica sobre a retórica. O Discurso seria predominantemente judiciário - ao defender Pedro de Almeida em sua repressão aos acusados na revolta - e demonstrativo - em louvor às virtudes do conde general e censurando os vícios dos rebeldes vis. ${ }^{21}$ Mediante exemplos e entimemas, o texto persuade o leitor da verossimilitude da narrativa, construindo sua versão sobre o castigo da revolta de 1720 de forma análoga a outros motins.

Em Vila Rica e Ribeirão do Carmo, o contraste com os vilões éfundamental no estilo da redação. Evidencia-se o caráter de Pedro de Almeida, reproduzindo seu ponto de vista por argumentos plenos de elogios, vitupérios e emoções que amplificam os efeitos, como a cólera dos deuses ante a

\footnotetext{
${ }^{19}$ A citação da nota 8, inspirada nas Metamorfoses de Ovídio, alude aos quatro elementos primordiais: terra, água, fogo e ar (Ovídio, 2017, p. 47).

${ }^{20} \mathrm{Na}$ carta escrita a d. João V em 21 de julho de 1720, o governador Pedro de Almeida resume a revolta como uma "conspiração mui semelhante a de Catalina [sic]" (Magalhães, 1862, p. 552). Nas cerca de 433 notas inéditas do Discurso, Salústio é referenciado em 37 e Cícero, em 34

${ }^{21}$ A acepção de discurso político da retórica aristotélica, ao evidenciar a deliberação consensual e futura da polis sobre o caso, não se coaduna ao Discurso. Como vimos, nele ressalta outra lógica de ação política.
} 
insolência dos amotinados..$^{22}$ No Discurso, as induções dos exemplos de histórias e fábulas são mais numerosas do que as deduções próprias dos entimemas, a fim de captar o julgamento favorável do suposto leitor. Com ritmo e jogos de palavras, o manuscrito comporta duas grandes partes, conforme anotações do estagirita: a exposição narrativa da revolta e argumentos com as razões para ter sido aplicado o castigo, embora as analogias a outras histórias estejam presentes em ambas. O prólogo e o epílogo são integrados ao início e ao fim das duas partes (Aristóteles, 2011).

Nas muitas notas marginais, Luís de Camões é o autor mais citado, com 41 remissões a suas líricas e épicas, além dos instantes em que seus versos cadenciam o texto central. O Discurso se situa num período de grande recepção camoniana, quando a citação, a glosa e a recriação de trechos de sua obra demonstram a agudeza do poeta ou prosador. Camões exercia uma atração estética pelo deleite de sua poesia capaz de mover afetos com jogos verbais e decoro. Como os autores portugueses narravam fatos distintos, eles retomavam apenas parte do fraseado do poeta quinhentista nos episódios, sem conteúdos e significados originais. Assim ocorre no Discurso, com uma celebração epidérmica da pátria e da expansão lusas. Mais do que o desejo de emulação, percebe-se uma atitude reverencial ante a qualidade do poeta (Cunha, 2011, p. 172-176). ${ }^{23}$

Abre-se, então, o caminho para as interfaces entre prosa e poesia mimética, produtora de imagens verossímeis, distintas das ações objetivas. De acordo com Aristóteles, o poeta - em especial o trágico - reelabora mitos antigos e gera catarses ao manipular emoções, representando criativamente as coisas como poderiam ou deveriam ser, e não como são. Decorre daí a diferença entre o poeta e o historiador, para além dos eventos descritos em verso ou prosa. Ao se referir ao universal, a poesia seria mais filosófica e elevada do que a história, presa ao particular (2015, p. 98).

Esses aspectos estariam presentes no Discurso com personagens mimetizadas pelo vício ou pela virtude, como o herói Assumar, dignificado ao modo de outros por suas ações? O códice de 1720 não constitui uma tragédia teatral com reviravoltas e reconhecimentos explícitos. Mas, como os versos camonianos, seu texto se assemelha à forma épica, ao emular feitos na

\footnotetext{
22 Por exemplo: "Pelo / menos eu acho, que depois, que se prin- / cipiou a tirar ouro, se viram as pri- / meyras duvidas, e contendas no mun- / do: retirou-se a justiça para o Céo, e / produzio a terra gigantes, e poderozos, / que atrevidos, rebeldes e insolentes / intentaram levantar-se contra o / seu soberano." E: "Ainda depondo as coroas, de que / o laureou a campanha, e despindo / as virtudes, de que o adorna o mo- / ral, se deviam por esta acção ao Co'- / de os triumphos, que aos Governa- / dores, que a seu successor entrega- / vam pacifica, e sogeita a provincia / decretou Roma; mas se o Capito- / lio o não vio victoriozo, e ovante nos / carros do seu triumpho, velohâ na / carroça dos applausos triumphan/ te, e coroado à posteridade vindoura, / que à sua fama emula ào tempo, / e à mesma eternidade, segura, mais / que nas memorias, erigir nas admirações para exemplar de Gover- // nadores e Principes, immortal es- / tatua." APM, AVC17 , imagens 003 e 236 da cópia digital.

${ }^{23}$ Por exemplo, quando a narrativa da revolta é seguida pela citação das oitavas de Camões sobre Santa Úrsula: "O mesmo passava / em Villa Rica, concorria por hu'a / parte o povo à ouvir ler as cartas, / e editaes do Conde, e ficava satis- / feito, brando, e alegre: acudia por / outra a consultar com os agen- / tes dos cabeças às suas cazas, / e de lá corria azedo, turbulento, / furiozo com a nova suggestam, / de que tudo eram maximas do / Conde para os enganar, o que // ao povo novamente alvoratava; e / movia a perturbar-se. / Ó povo cego, e leve, as torpes fezes / Aparta do ouro puro, e lansa fora, / Torna-te à teu pastor perdido gado, / Olha que vás sem elle mal guiado." APM, AVC-17, imagem 069 da cópia digital.
} 
Índia ou em Vila Rica, heróis pretéritos e deuses do Olimpo. Nas epopeias em prosa, gênero híbrido em voga no século XVII estudado por Adma Muhana, adaptavam-se preceptivas clássicas visando conciliar a poética — em princípio votada apenas ao deleite - e a retórica elaborada para persuadir e ensinar. Em geral, as epopeias modernas se centravam nas vidas de heróis apaixonados e seus rivais. Mas havia outros temas, passando-se a agregar à narrativa principal episódios de situações e tempos diversos, gerando múltiplos personagens, relatos, lugares, tempos, caracteres e modos de dizer subordinados ao enredo. As fábulas unas, extensas e com argumentos rompiam com a distinção aristotélica entre as ações cronológica e poética - com mais conexões verossímeis. O vínculo entre verossimilhança e unidade conferia decoro, ao retratar pessoas de modo grave, incentivando a recompensa dos virtuosos e o castigo dos viciosos no decurso da narrativa (1997, p. 192-217).

O Discurso parece ser uma narrativa épica, pois a seu modo também imitava o universal e o figurado da poesia, embora nele se narrasse sobretudo os eventos históricos, com nomes particulares. Nesse texto, os motins passados e presentes, os mitos e a sofística sagrada aparecem atrelados à revolta de 1720, efetuando a gradação entre a história coeva e as fábulas acessórias. Há variedade na unidade sem desregramento, como nas obras de Homero ou Virgílio, ${ }^{24}$ plenas de figuras e significados. Cícero e Quintiliano, por sua vez, valorizaram o papel da digressão por meio de exemplos que evidenciam a coisa, ${ }^{25}$ ao modo das causas judiciárias expostas em forma de fábula - um percurso agradável com afetos e ornatos para juízes fictícios. A passagem do verso à prosa acentuou esses elementos (Idem, p. 197-276).

\footnotetext{
${ }^{24}$ Virgílio, citado 37 vezes em notas no Discurso, se inspirou em Homero. Há temas imitados das Geórgicas ou da Eneida que aumentam a capacidade de comunicação do manuscrito - sobre a relação entre Roma e Cartago, a ambiguidade de Júpiter etc. - ao modo do poeta latino notável por essa intertextualidade. Há também, no Discurso, a busca de estilo similar a Virgílio no uso de anáforas na segunda parte; no excursus final encomiástico de efeito, com menção ao Capitólio; e no ritmo por vezes claro-escuro do documento, como nas Geórgicas. Como Eneias, Pedro de Almeida é um herói em meio à guerra constante. Os valores estoicos aparecem também num messianismo de oráculos difuso no texto e na ideia de missão do conde general. Eles lembram Sêneca, citado 22 vezes nas notas por suas epístolas, tragédias - recriando peças da mitologia grega com grande carga emocional e reflexões sobre o poder tirânico -, pelo tratado De clementia e pelo diálogo De ira, também conhecido por suas anáforas, antíteses e técnicas retóricas na esteira da filosofia diatríbica (Citroni, 2006, p. 447-498 e 719-760; Pereira, 2009, p. 246-327).

${ }^{25}$ Não há como resumir a influência de Cícero na retórica, na política e na filosofia mediando as relações entre culturas grega e romana, oratória e literatura. Mencionado 15 vezes no texto do Discurso e 34 nas notas, ele se notabilizou pelo impacto emotivo de seu estilo com abundância de palavras, expressões e amplificações - na literatura latina, a construção do período em prosa é invenção sua. Cícero é citado no Discurso, por exemplo, pelo colóquio De legibus, ao enfatizar a aplicação das penas ante os delitos; por De officiis, escrito durante a luta contra Marco Antônio no Egito, alertando para cuidar de todas as partes da República, ou sobre os instintos rebeldes dos mineiros, ou sobre os fundamentos da justiça; pelo diálogo De divinatione, do qual se mencionam os vaticínios da sibila, profetizando a violência em analogia aos motins naturais das Minas. Sobre as catilinárias, há um exercício de interpretação (Monteiro, 2015). Não obstante Cícero, no discurso Pro Milone, alivie certos pormenores para desviar a atenção em favor do assassino de Clódio, há trechos que enfatizam os crimes dos rebeldes. Da mesma forma, a retórica violenta empregada nas Philippicae contra Marco Antônio evidenciou os desatinos dos amotinados, inclusive com os elementos satíricos daqueles panfletos. Quanto aos livros escritos para formar Bruto orador, há o conselho sobre a prudência de antecipar-se aos conflitos (Citroni, 2006, p. 263-310; Pereira, 2009, p. 125-180). Nos séculos XVII e XVIII foi sobretudo o Cícero "cívico" que reviveu nos escritos (Grafton, 2010, p. 197).
} 
Conquanto Aristóteles tenha sublinhado a prevalência da ação na tragédia, no gênero épico os exemplos humanos emocionavam os leitores. Seguindo a retórica latina, preceptivas dos séculos XVI e XVII enfatizam caracteres e pensamentos de personagens. Doravante, protagonistas e antagonistas seriam qualificados por seus retratos, buscando-se o decoro na verossimilhança de ditos, costumes e atos. As personagens épicas, virtuosas ou viciosas ao extremo, têm caráter diverso das trágicas, sem sofrer com suas paixões (Idem, p. 111-155). No Discurso, as descrições morais encontram respaldo nos escritos de Salústio sobre Catilina e Jugurta. Os retratos elaborados pelo historiador romano pautam as caracterizações vis de Pascoal da Silva Guimarães, Manoel Nunes Viana, ${ }^{26}$ Sebastião da Veiga Cabral e Felipe dos Santos.

Em revanche, o conde general reina junto a heróis antigos e/ou fabulosos, acima do mundo de vícios e sedições. O perfil de monografia histórica e o estilo áspero da narrativa de Salústio seriam outros aspectos comuns ao Discurso (Red, 2001; Citroni, 2006, p. 411429). Nesse tempo, o uso dos discursos diretos já era démodé, mas o modelo catilinário era famoso nos cursos de retórica. Os jesuítas, interessados em conflitos políticos na América, se valiam desses ornatos. Eles tinham sensibilidade teatral, gostavam de reflexões audaciosas e lidavam com a diversidade cultural (Ginzburg, 2002, p. 80-99). Como vemos, a seleta de temas e estilos nos manuscritos pode advir menos da verve de Pedro de Almeida, e mais dos inacianos que o secundavam.

No Discurso, também varia-se o modo de narrar. A distinção original entre poesia e história e suas adaptações nos gêneros híbridos resultou em mudanças na aplicação do sujeito, haja vista que o poeta deve se retirar após iniciar o poema, fingindo-se independente da fábula a fim de mostrá-la grande, enquanto o historiador narra as coisas do seu ponto de vista (Muhana, 1997, p. 208- 210). No Discurso, há o uso da primeira pessoa do singular em vários momentos, e na maior parte do texto é empregado o tom impessoal, com o caráter e as ações de Pedro de Almeida e outros referidos na terceira pessoa.

A leitura desses trechos não possibilita afirmar uma relação direta entre o uso diferenciado de pronomes e a prevalência das figuras do historiador ou do poeta, pois no Discurso o relato impessoal, não raro, se refere a eventos da revolta de Vila Rica, por vezes conjugados à poesia, enquanto opiniões são emitidas sob a fórmula do "eu" para os vários

${ }^{26}$ O plebeu e comerciante de gado Manoel Nunes Viana, potentado com ações do sertão da Bahia até as Minas e mandante local durante a Guerra dos Emboabas, foi reconhecido por seu letramento no Discurso. Ele patrocinou a impressão de obras como o Compêndio narrativo do peregrino da América, de Nuno Marques Pereira (1725), e tomos das Decadas da Asia, de Diogo do Couto (1736), em busca de prestígio (Romeiro, 2008, p. 156-178; Palomo, 2014). Mas o Discurso e a Noticia conheceram outras recepções, explicadas neste artigo pela nobreza de Pedro de Almeida e/ou pelo teor conflituoso de suas narrativas. 
motins em Minas, ocasionalmente associadas a aspectos do maravilhoso. ${ }^{27}$ De todo modo, descarta-se, pelo exame das fontes, a hipótese de uma coincidência literal entre trechos de cartas escritas por Pedro de Almeida a d. João V e momentos em que, no Discurso, se utiliza a primeira pessoa do singular.

As cartas podem ter sido consultadas para a redação do códice, mas não foram copiadas. Na Noticia, por sua vez, Assumar e os homens de 1720 são referidos na terceira pessoa, e não há quase o emprego da primeira. Como vimos, tal manuscrito foi redigido sem digressões teóricas ou fabulosas, mas nada impede que o poeta imite o modo de narrar do historiador, alegando a verdade do narrado ou julgando e sentenciando (Idem, p. 81-91). A alternância de sujeitos no Discurso, portanto, parece se tratar de um recurso retórico complexo, passível de maior investigação.

O uso alterado da primeira ou terceira pessoa faz também com que o tempo presente, bastante utilizado no gênero épico, o torne distinto do puro relato histórico, ao apresentar de forma atual e dramática os sucessos imitados. Recomenda-se, assim, começar a narrativa pelo meio dos tempos, a fim de que as ações passadas e futuras - o reconhecimento dos feitos do conde general - surjam a partir da ação central. Esse começo in media res gera uma hierarquia de ações, caracteres e pensamentos em função do evento principal, compondo um verossímil superior que subverte a cronologia da história, com idas e vindas, desde o meio da ação até o princípio, e daí em direção ao fim (Idem, p. 202-210). Embora ambos os textos se apresentem afinados com o relato ordenado dos eventos de 1720, o Discurso e a Noticia começam com a expressão "vários têm sido os motins, e sublevações, que em diversos tempos houve nas Minas", narrando-se primeiro os acontecimentos de 1719, para depois enveredar pela revolta de Vila Rica, em analogia a episódios antigos e passados (APM, AVC17, imagem 001; IEB-USP, AL-61, p. 1).

Sublinhe-se ainda a disposição escrita do Discurso, com citações literais ou alusivas a muitas autoridades no centro e nas margens das páginas, engrandecendo a narrativa e seus personagens, enquanto na Noticia as notas marginais glosam os conteúdos dos parágrafos numerados no texto principal, com feição mais despojada. Esses aspectos diagramáticos propiciam analisar em termos materiais os dois documentos.

\footnotetext{
${ }_{27}$ Por exemplo, o trecho citado na nota 8 para o emprego da 1ª pessoa e o seguinte soneto para a 3a: "Esse, que sobre o monte rayo soa, / Rompendo a grossa nuvem, q' o gerara, / Hé do Conde benigno empreza rara, / Com que a sua justiça se coroa. / Tema a soberba o danno, que apregoa / O rayo, que suspensa a mam dispara, / Poes nos fataes estragos, q' prepara, / Ao grande aviza, quanto ao monte atròa. / Màs se do monte a mam o dano empreende / Com a suspensam, que os tenta na devisa, / Nam vê, que das ruinas o defende? Oh quanta aqui piedade se devisa! / Visto estâ, que os estragos não pretende, / Quando, antes do danno, o rayo avisa." APM, AVC-17, imagem 042 da cópia digital.
} 


\section{O papel da tinta}
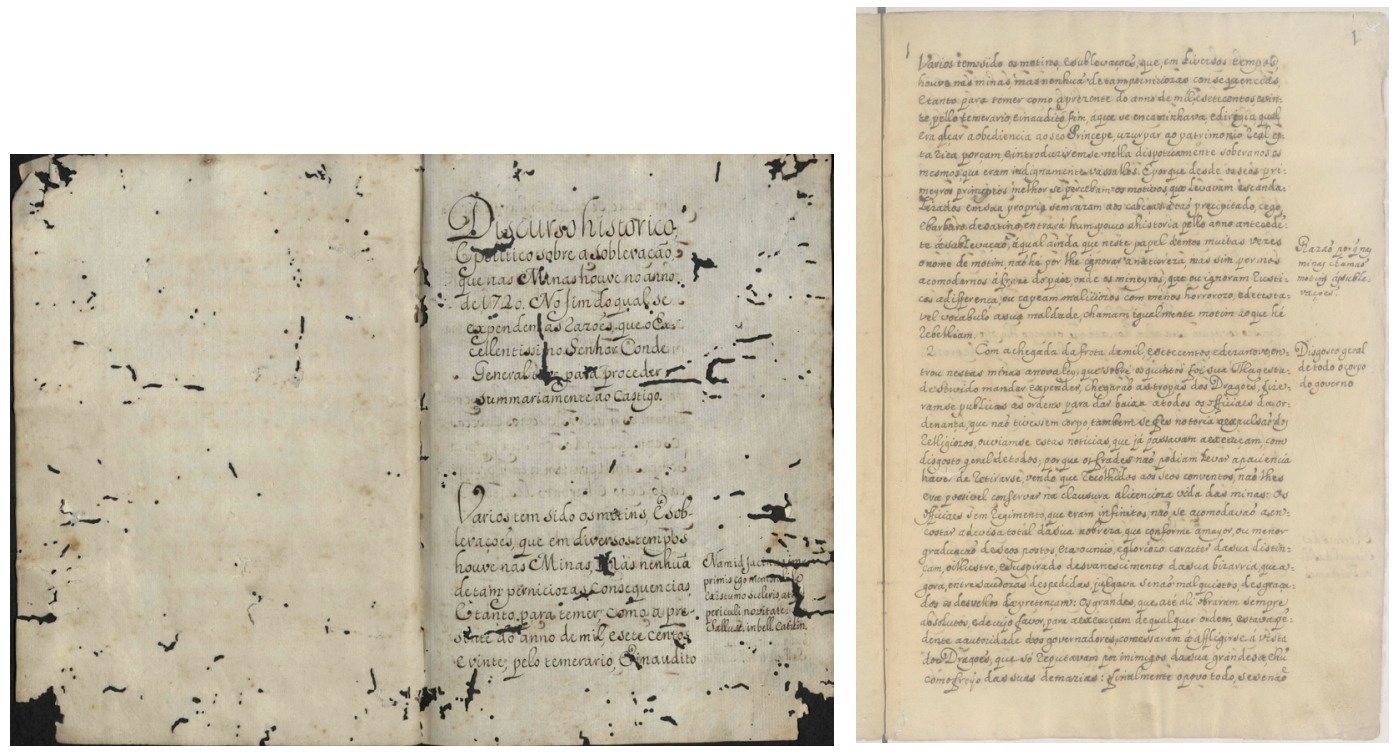

Figura 1 - Formas de apresentação do Discurso, à esquerda, e da Noticia, à direita (APM, AVC-17; IEB-USP, AL-61).

A natureza distinta das narrativas se expressa em suas formas de apresentação (fig. 1). O Discurso - com o relato dos fatos, a justificativa político-filosófica das decisões de Pedro de Almeida e várias digressões culturais - se apresenta sob a forma de um documento encadernado com dimensões de 21x15cm, contendo 240 fólios agrupados em trinta cadernos, com assinatura numérica original na borda superior direita e numeração de fólios proveniente de época posterior. As assinaturas numéricas são um recurso usual na diagramação tipográfica para facilitar a dobradura dos fólios após sua impressão, a fim de unir os cadernos na sequência correta para encaderná-los, sendo normalmente posicionadas no pé da página. Sua presença nesse manuscrito sugere que ele foi redigido em cadernos previamente separados, visando ordená-los à medida que se copiava o texto para posterior costura e encadernação.

Os cadernos do códice foram formados pela junção de quatro fólios de papel de trapo tipo Almasso ${ }^{28}$ dobrados ao meio. O corpo do códice é composto por papéis de fibra de linho de duas

${ }^{28}$ O papel de tipo Almasso é um bifólio composto por quatro páginas com dimensões em torno de 30×20cm, fabricado originalmente para uso de chancelaria. A marca d’água se localiza no centro de um dos lados do bifólio, e a indicação Almasso, no centro do outro. Sendo um bifólio, estava pronto para ser costurado, caso necessário, de forma individual ou com a junção de outras unidades. 
marcas diferentes, identificadas por suas filigranas, ${ }^{29}$ com características do século XVIII, de boa qualidade, com a mesma gramatura, apresentando-se claros, levemente transparentes, com boa distribuição de fibras e sem sujidades internas. A encadernação tem tipologia setecentista, com pasta formada por papel laminado e revestimento em couro de carneiro de coloração castanha e decoração moucheté (pequenas manchas escuras), de tipologia simples, usando-se nas guardas o mesmo papel do corpo do manuscrito. O dorso da encadernação apresenta uma decoração floral entre os cinco nervos e uma etiqueta colada com a inscrição DISCVRSO HISTORICO. Após ter sido perfilado para acertarem-se as bordas externas e costurado, recebeu nos cortes uma decoração simples feita com pequenos pontos vermelhos.

A organização da mancha gráfica confere ao texto uma aparência elegante pela sua letra regular, de módulo médio, com ligaduras escassas entre os sinais gráficos e eventuais entre palavras, denotando uma escrita lenta e cuidadosa. As entrelinhas e as margens são largas e extremamente uniformes em todo o documento, sendo as bordas externas mais amplas para abrigarem a inscrição das glosas. O texto foi manuscrito com dois tipos distintos de tinta metaloácida, que atualmente apresentam colorações diferenciadas devido à degradação, sendo uma de tonalidade sépia, encontrada no corpo do texto, e outra nas glosas, com coloração aproximada ao negro, tonalidade das tintas metaloácidas novas. Essas características esclarecem as etapas da escrita e indicam um tempo relativamente longo de produção do códice, tendo sido necessária a preparação de uma nova tinta para completar as notas, incluídas após a conclusão do texto principal.

Por sua vez, a Noticia se afigura como um documento encadernado com dimensões de $32 \times 22 \mathrm{~cm}$, com cadernos formados pela junção de bifólios de papel de trapo tipo Almasso sem dobrar, da mesma marca utilizada no Discurso - a lua crescente com pontas voltadas para baixo. Trata-se de um documento de 29 fólios, com todas as 58 páginas numeradas originalmente. Mas sua encadernação é própria do século XIX ou do início do XX, com guardas em papel de fibra de madeira e revestimento de tecido para encadernação de boa qualidade. A organização da mancha gráfica é configurada com espaço de entrelinhas e margens internas estreitas, em contraposição às largas margens externas. A letra redigida com apenas um tipo de tinta metaloácida é regular, de módulo pequeno. O manuscrito apresenta mais ligaduras entre as letras, indicando uma escrita mais rápida e fluida. O texto é organizado em parágrafos numerados, com glosas nas margens externas que resumem seu conteúdo.

O Discurso e a Noticia sofreram correções ao longo do processo de escrita, sendo algumas feitas de forma pontual para substituir letras ou palavras e outras, mais extensas, com modificações em toda a frase. No Discurso, essas correções foram realizadas de dois modos

29 Um dos papéis apresenta marca d’água com a cruz de São Jorge coroada e ladeada por dois grifos alados, tendo na parte inferior duas circunferências tangentes com as inscrições GUI e I; o outro contém um emblema com lua crescente com as pontas para baixo, encimada por uma cruz com duas circunferências abaixo, a primeira com uma estrela de cinco pontas e a segunda com a letra M. Ambas as filigranas indicam um papel de origem genovesa. 
distintos. Um quase imperceptível, como uma rasura sutil da linha para posterior inscrição de novas letras, com o mesmo tipo de tinta usado anteriormente. Essa correção foi usada para substituições pontuais e atualmente não apresenta vestígios de sua execução, sendo perceptível apenas sob fluorescência de luz ultravioleta. O outro tipo de correção tem um processo mais complexo, iniciado com a raspagem superficial da tinta e a colocação de uma massa feita com cera e pigmento branco de chumbo para preenchimento da rasura. ${ }^{30}$ Essa técnica foi usada tanto em áreas pequenas, para substituição de letras, quanto em maiores, para trocas de palavras ou sentenças inteiras - nas quais se empregou uma tinta de densidade maior do que a do corpo do texto. Atualmente, essas áreas são perceptíveis, pois nelas a tinta se mantém preta, porém craquelada, já que a textura da massa não permite uma perfeita adesão ao suporte (fig. 2). No momento da escrita, todavia, essas correções, hoje com tonalidade escura, deviam ser imperceptíveis, mantendo a elegância do projeto gráfico do manuscrito.

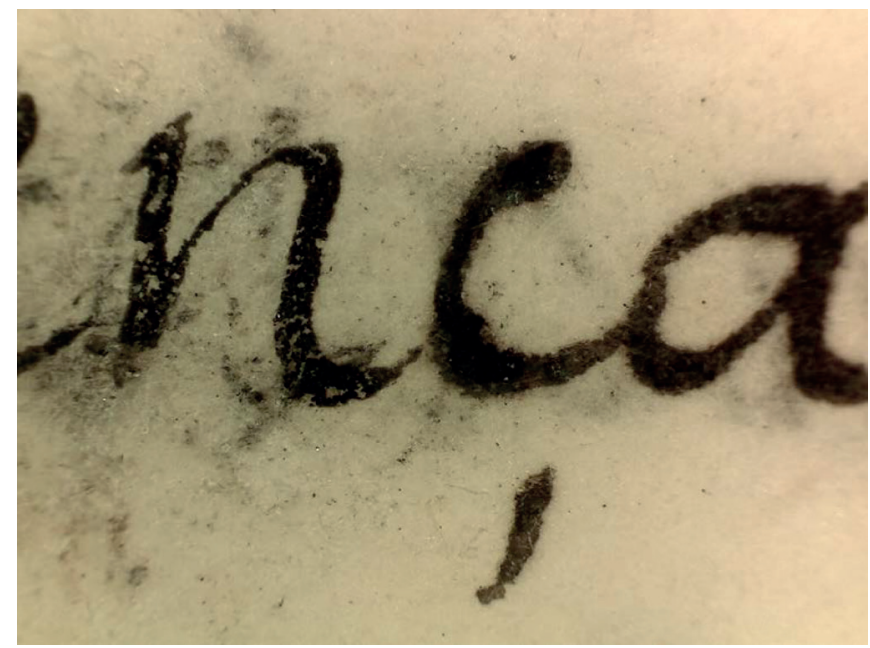

Figura 2 - Comparação entre a tinta da correção, mais forte, e a tinta original do texto, esmaecida (APM, AVC-17, fólio 75v, linha 16). Foto dos autores com microscópio digital USB em aumento de 60x.

Já na Noticia foram usadas duas técnicas de correção: a primeira, apresentada acima, com raspagem sutil da letra, e outra, com a supressão da palavra inteira com um risco de tinta e a inscrição de uma nova na entrelinha superior, com letra menos cuidada. Destaca-se a

\footnotetext{
30 Técnica descoberta após exames no Laboratório da Ciência da Conservação da Escola de Belas Artes na Universidade Federal de Minas Gerais. Sob microscopia óptica, foi possível reconhecer a camada branca, cuja constituição apresenta branco de chumbo, identificado nos exames de espectroscopia de fluorescência de raio x e na análise microscópica para chumbo - abertura por ácido nítrico e precipitação de iodeto de potássio. O branco de chumbo era um pigmento utilizado para clarear tintas usadas em manuscritos nas Minas no início do século XVIII (Gonçalves, 2015, p. 64).
} 
correção na última linha da página 58 - a obliteração de uma informação completa por meio da aplicação de grande quantidade de tinta, formando um borrão denso. Pela localização dessa inscrição na folha, supõe-se ter sido ela uma assinatura. Hoje ela é totalmente ilegível devido à oxidação do papel e da tinta. Mas, como vimos, autores que consultaram o documento décadas atrás (Alberto Lamego, talvez Affonso Taunay e Rodolfo Garcia) chegaram a supor que o riscado cobria o nome do conde de Assumar como autor do manuscrito.

A análise codicológica descreve o documento no tempo e no espaço, procurando nos elementos estruturais do códice as evidências de um projeto de execução, tentando elucidar o significado relativo de seu destino (Correia, 2017, p. 25). As informações textuais, materiais e visuais dos dois documentos podem levar a caminhos para esclarecer as questões levantadas: por quem, para que, quando e onde os dois textos foram pensados e redigidos, e quais seriam as relações e as diferenças entre eles (Almada, 2018). Indubitavelmente, os dois manuscritos foram redigidos pelo mesmo autor gráfico, com uma mesma tipologia de letras, que se distinguem apenas no tamanho e no apuro da caligrafia, em momentos próximos, no século XVIII e no mesmo local, dada a correspondência entre os tipos de papel utilizados.

Tratava-se de um profissional qualificado, que lidava fluentemente com a escrita cursiva em português, latim e espanhol. Ele tinha o domínio da pena e dos padrões gráficos e ortográficos, embora dentro da perspectiva de ausência de uma norma culta para o português vigente naquele período (Marquilhas, 2001, p. 112). Verifica-se essa prática nas formas diferentes de grafar as palavras e pontuar os períodos, ao analisar cada documento per se, e também de forma comparada entre os dois - grosso modo, elas seriam mais simples e diretas na Noticia do que no Discurso. Tal profissional gráfico pode ter sido um escrivão particular contratado para o serviço. Mas, devido à condição social do interessado Pedro de Almeida, é provável que tenha sido um dos jesuítas apaniguados, ou um amanuense a serviço do governador de capitania.

Devido à formulação gráfica e aos tipos de correção encontrados no Discurso, supõe-se que o manuscrito do APM seja a versão final de um texto previamente concebido em outros papéis de rascunho. Nesse códice muito bem cuidado, a correção de palavras e frases inteiras, retocadas com branco de chumbo e uma tinta mais densa que a utilizada no corpo do texto, sugere a realização de uma revisão crítica posterior do texto pelo(s) autor(es), após o manuscrito estar completamente trasladado. Houve, assim, uma preocupação em apurar palavras e ideias, buscando não deixar margem a dubiedades. Faz-se plausível ainda que o Discurso tenha sido elaborado e redigido em primeiro lugar, tendo sido trasladado parcialmente para compor o texto da Noticia. Ao comparar as duas transcrições dos documentos, percebe-se que palavras e expressões revisadas no Discurso foram utilizadas no manuscrito do IEBUSP. Portanto, a dinâmica de escrita um tanto errática dos dois documentos, com ensaios 
e apuros de correções, possibilita vislumbrar um ambiente redacional coletivo, não se sabe ainda onde e quando - hipótese corroborada pelas evidências materiais. ${ }^{31}$

Encadernada, a versão final do códice existente no APM estava pronta para circulação ou preservação, configurando-o como um livro manuscrito, mas sem página de rosto ou colofão, ou seja, sem registros de autoria, data e local. Contudo, nada impedia que o Discurso fosse editado posteriormente, em versão impressa custeada pelo suposto mentor ou por outrem, tendo em vista que seu texto é uma construção sólida e finalizada. Mesmo edições anônimas como essa poderiam ser impressas, fazendo-se uso ou não do recurso a codinome ou falso local de publicação (Darnton, 2012, p. 68-69). Mas, como se sabe, as edições manuscritas guardavam algumas vantagens sobre o impresso (Bouza, 2001, p. 143), e nesse caso o valor de segredo, intimidade e garantia de integridade do teor do texto deve ser considerado, além de seu peculiar perfil literário. A diagramação elegante, limpa e de fácil leitura, as margens largas e a preocupação com a limpeza visual durante as eventuais correções, denotam um padrão superior e pouco econômico de escrita, voltado para um círculo de leitores de elite.

A tipologia da encadernação e o formato do documento, entretanto, sugerem que ele não teria sido um exemplar destinado à circulação oficial entre altas autoridades monárquicas, pois em geral as formalidades da Corte exigiam o uso de folhas grandes, como marca de reverência (Daybell, 2009, p. 659), além de uma encadernação luxuosa. Pelo contrário, o formato escolhido facilita o transporte e o manuseio, conquanto o exemplar do Discurso hoje conhecido não apresente marcas de grande manipulação.

Não se encontraram, até o presente momento, indícios da recepção do Discurso na Corte de Lisboa. Essas informações, associadas ao fato de o códice se achar, ao menos desde 1825, aos cuidados da casa de Linhares, fortalecem a hipótese de que o manuscrito do APM não foi entregue à Coroa como peça de defesa política de Pedro de Almeida ante o castigo impetrado em Vila Rica, como supõe em geral a historiografia. Por essa investigação, ele foi

\footnotetext{
31 Ao destacar o período pacato, após a repressão aos rebeldes e o fracasso da aprovação de uma casa da moeda, de quase oito meses vivido por Pedro de Almeida em Vila do Carmo até sua volta ao reino, em agosto de 1721, Tarcísio Gaspar fornece subsídios para pensar a possível elaboração do Discurso e da Noticia nesses tempo e local (2016, p. 187-188). As cartas de Pedro de Almeida ao bispo do Rio de Janeiro e ao primo, sinalizando que recorria aos jesuítas para ajuda-lo em "papéis", datam de janeiro desse ano (Souza, 1994, p. 26-27).
} 
pouco consultado, passando o tempo escondido nas prateleiras de casas nobres, entre os herdeiros do $3^{\circ}$ conde de Assumar até migrar para a livraria dos condes de Linhares. ${ }^{32}$

Por outro lado, a Noticia foi construída pelo recorte das informações encontradas no Discurso. Nessa versão, interessava sobretudo narrar os fatos ocorridos em 1720 em Vila Rica e Ribeirão do Carmo. A numeração dos parágrafos e a marca de temas nas glosas foram opções de organização do texto para facilitar a leitura e a busca de informações. A caligrafia mais rápida, o uso de fólios Almasso sem tratamento codicológico, a paginação e a ausência de encadernação coetânea sugerem que o texto foi produzido como um documento a ser compilado numa série de papéis vários, com manuscritos compreendendo notícias sobre diversos acontecimentos, a fim de circular sob a forma de relações de sucessos ou gazetas. Esse procedimento de resumo de um documento mais vasto seria comum desde o século XVI, a fim de alimentar uma rede de comunicação por papéis manuscritos (Bouza, 2001, p. 147).

Torna-se plausível admitir a existência pretérita de mais exemplares da Noticia. Apesar de a dimensão conflituosa e a responsabilidade política desse documento serem delicadas para a monarquia portuguesa, ele pode ter sido concebido como uma crônica histórica, ao veicular novidades sobre situações vividas com distanciamento e sem o limite das breves informações das gazetas (Lisboa, 2011, p. 22, 34). Ao contrário do Discurso, o manuscrito da Noticia foi consultado por muitas mãos, como atestam as sujidades encontradas nos cantos das folhas. Mas, infelizmente, não se pode determinar o tempo de criação dessas marcas, se feitas antes ou depois de sua aquisição por Alberto Lamego.

Em conclusivo, a historiografia mais preocupada com a fabricação de mitos contemporâneos, os fatos objetivos ou a autoria intelectual descurou de estabelecer relações entre dois expressivos manuscritos atribuídos ao $3^{\circ}$ conde de Assumar sobre a revolta de Vila Rica. Se as impressões parciais do códice do APM desestimularam os estudos comparados, no presente os novos aportes sobre cultura escrita e materialidade de documentos na época moderna ampliam o espectro de análise, permitindo identificar diferentes aspectos dos respectivos textos que, não obstante, têm origem comum.

\footnotetext{
${ }^{32}$ Ao preparar-se para voltar a Portugal em 1814 após a morte do irmão Pedro José de Almeida (3 marquês de Alorna) nas guerras napoleônicas, Leonor de Almeida Portugal - a poetisa Alcipe e também neta de Pedro Miguel de Almeida - foi informada pelo procurador encarregado da posse de seus bens que vários deles foram apanhados pela casa do "defunto conde de Linhares" (Rodrigo de Sousa Coutinho, morto em 1812), entre eles "a livraria formada com tanta inteligência e cuidado por meu Avô, meu Pai e meus Tios, os preciosos manuscriptos, tudo desapareceu". Suplica assim ao destinatário não identificado que interceda junto ao príncipe regente para realizar inventários que esclareçam onde estavam "estes importantes objetos", como propriedade inalienável do seu direito. O $3^{\circ}$ marquês de Alorna foi declarado traidor da pátria em 1810 por ter aderido ao lado francês. José António de Sousa Coutinho, o Principal Sousa, irmão do falecido conde de Linhares, era então um dos regentes de Portugal, tendo comandado o confisco dos bens de Alorna. Na grande relação de livros e manuscritos a serem doados à Real Biblioteca Pública em 1819 - futura BNP - já não aparece o Discurso, todavia encontrado na livraria dos condes de Linhares desde 1825, como sinaliza a cópia da BNB, e comprado pelo governo mineiro em 1895. Arquivo Nacional da Torre do Tombo, Casa de Fronteira e Alorna, n. 174 e Juízo da Inconfidência, Casa de Alorna, maço 1, n. 1.
} 
O estudo desses manuscritos ultrapassa o âmbito político ao perscrutar técnicas retóricas, gêneros antigos e modernos, papéis, letras, cadernos e tintas, fazendo com que também eles passem a "falar". Por meio de hipóteses fundamentadas, vislumbram-se indícios de suas distintas circulações, contribuindo para elucidar perguntas há muito esboçadas. Percebe-se, assim, a relevância de exames textuais e materiais detalhados, bem como da comparação entre exemplares, para evitar o risco de generalizações ante um documento mais conhecido apenas por versões parciais e impressas, no caso do Discurso.

A história da cultura escrita se apoia em estudos sobre as maneiras de produção, difusão e preservação (Gómez, 2001, p. 19-20), compreendendo os textos como objetos materializados, construídos e lidos em circunstâncias específicas, interpretados por suas forma e substância (McKensie, 1999, p. 13-14). A ligação entre estrutura, função e significado é fundamental para entendê-los em sua historicidade, numa espécie de arqueologia filológica que, a propósito, guarda semelhanças com o perfil do historiador pensado por Aristóteles ao perseguir as relações entre história, retórica e prova de modo peculiar (Ginzburg, 2002, p. 47-79; Regoliosi, 1993). Se não é possível ainda desvendar todas as condições de produção e os destinos dos documentos em tela, procurou-se aqui demonstrar o valor da cautela conjugada ao enfrentamento intenso, em suma, do escrito e do papel.

\section{Agradecimentos}

Adma Muhana, André Cerqueira, Caio Boschi, David Martín Marcos, Douglas Dias, Heloisa Starling, João Cura D’Ars Figueiredo, Heloísa Bellotto, Iris Kantor, Júnia Furtado, Leila Algranti, Leonardo Ramos, Lucia Guimarães, Luciano Figueiredo, L. Filipe Silvério Lima, Luiz A. C. Souza, Marco Antonio Silveira, Nuno Monteiro, Selma Otília Gonçalves, Tarcísio Gaspar, Tiago C. P. dos Reis Miranda, projetos CNPq 163188/2015-7, 424389/2016-9, 302307/2016-8 e Capes 585/2015. 


\section{Bibliografia}

ALMADA, Márcia. Cultura material da escrita ou o texto como artefato. In: CONCEIÇÃO, Adriana Angelita da; MEIRELLES, Juliana Gesuelli (Orgs.). Cultura escrita em debate: reflexões sobre o império português na América - séculos XVI a XIX. Jundiaí: Paco, 2018, p. 17-40.

ANASTASIA, Carla. Sedição de Vila Rica. In: ROMEIRO, Adriana; BOTELHO, Angela Vianna (Orgs.). Dicionário histórico das Minas Gerais: período colonial. Belo Horizonte: Autêntica, 2013, p. 374-376. ARISTÓTELES. A política. São Paulo: Martins Fontes, 2006.

Poética. São Paulo: Editora 34, 2015.

Retórica. São Paulo: Edipro, 2011.

BALDINI, Artemio Enzo (Org.). Aristotelismo politico e ragion distato: atti del Convegno Internazionale di Torino 11-13 febbraio 1993. Florença: Leo S. Olschki, 1995.

BELO, André. As gazetas e os livros: a Gazeta de Lisboa e a vulgarização do impresso (1715-1760). Lisboa: Imprensa de Ciências Sociais, 2001.

Nouvelles d'Ancien Régime: la Gazeta de Lisboa et l'information manuscrite au Portugal (1715-1760). Tese (doutorado em história), École des Hautes Études en Sciences Sociales, Paris, 2005.

BLUTEAU, Raphael. Vocabulario portuguez \& latino: aulico, anatomico, architectonico. Coimbra: Collegio das Artes da Companhia de Jesus, 1712-1728.

BOSCHI, Caio César. Os leigos e o poder: irmandades leigas e política colonizadora em Minas Gerais. São Paulo: Ática, 1986.

BOUZA, Fernando. Corre manuscrito: una historia cultural del Siglo de Oro. Madri: Marcial Pons, 2001.

BOXER, Charles R. A Idade de Ouro do Brasil: dores de crescimento de uma sociedade colonial. São Paulo: Companhia Editora Nacional, 1969.

CARVALHO, Feu de. Ementario da historia mineira: Felippe dos Santos Freire na sedição de Villa Rica em 1720. Belo Horizonte: Historicas, 1933.

CARVALHO, José Murilo de. A formação das almas: o imaginário da República no Brasil. São Paulo: Companhia das Letras, 1990.

GÓMEZ, Antonio Castillo. El tiempo de la cultura escrita: a modo de introducción. In: (Org.).
Historia de la cultura escrita: del próximo Oriente Antiguo a la sociedad informatizada. Gijón: Trea, 2001, p. 15-25. CITRONI, Mario (Org.). Literatura de Roma antiga. Lisboa: Fundação Calouste Gulbenkian, 2006.

CORREIA, Inês Isabel S. de A. dos S. Estudo arqueológico dos Códices Iluminados do Fundo Laurbanense: as intervenções de conservação num corpus medieval. Tese (doutorado em história da arte medieval), Universidade Nova de Lisboa, Lisboa, 2015.

CUNHA, Mafalda Ferin. Camões na poesia barroca portuguesa. In: SILVA, Vítor Aguiar e (Org.). Dicionário de Luís de Camões. São Paulo: Leya, 2011, p. 172-176.

CUNHA, Norberto Ferreira da. Elites e acadêmicos na cultura portuguesa setecentista. Lisboa: Imprensa Nacional/ Casa da Moeda, 2006.

DARNTON, Robert. O diabo na água benta ou a arte da calúnia e da difamação de Luís XIV a Napoleão. São Paulo: Companhia das Letras, 2012.

DAYBELL, James. Material Meanings and the Social Signs of Manuscript Letters in Early Moderns England. Literature Compass, n. 6, v. 3, 2009, p. 647-667.

FONSECA, Alexandre Torres. A revolta de Felipe dos Santos. In: RESENDE, Maria Efigênia Lage de; VILLALTA, Luiz Carlos (Orgs.). História de Minas Gerais: as minas setecentistas. Belo Horizonte: Autêntica/ Linha do Tempo, 2007, p. 549-566.

FONSECA, Manoel da. Vida do venerável padre Belchior de Pontes da Companhia de Jesus da província do Brasil. Lisboa: Francisco da Silva, 1752.

FREYRE, Gilberto. Sobrados e mucambos: decadência do patriarcado rural e desenvolvimento do urbano. Rio de Janeiro: José Olympio, 1985.

FUMAROLI, Marc. L'âge de l'éloquence: rhétorique et res literaria de la Renaissance ao seuil de l'Époque Classique. Genebra: Droz, 2009.

GARCIA, Rodolfo. Os levantes de Pitangui e a revolta de Vila Rica (1720). Anais da Biblioteca Nacional (Rio de Janeiro), v. LXV, 1943, p. 121-153.

GASPAR, Tarcísio de Souza. Palavras no chão: murmurações e vozes em Minas Gerais no século XVIII. São Paulo: Annablume, 2011.

Tapanhuacanga em ruínas: história do palácio velho de Ouro Preto (c. 1660-1825). Tese (doutorado 
em história social), Universidade de São Paulo, São Paulo, 2016.

GINZBURG, Carlo. Relações de força: história, retórica, prova. São Paulo: Companhia das Letras, 2002.

GOMES, Plínio Freire. Um herege vai ao paraíso: cosmologia de um ex-colono condenado pela Inquisição (1680-1744). São Paulo: Companhia das Letras, 1997.

GONÇALVES, Maria Furtado. Separados no nascimento: estudo de técnicas, materiais e estado de conservação de dois manuscritos iluminados do século XVIII. Dissertação (mestrado em artes), Universidade Federal de Minas Gerais, Belo Horizonte, 2015.

GRAFTON, Anthony et al. (Orgs.). The classical tradition. Cambridge: Harvard University Press, 2010.

GRAVATÁ, Hélio. Contribuição bibliográfica para a história de Minas Gerais. Revista do Arquivo Público Mineiro (Belo Horizonte), ano 27, dez. 1976, p. 283-286.

. Resgate bibliográfico de Minas Gerais. Belo Horizonte: Fundação João Pinheiro, 1998.

LAMEGO, Alberto. Mentiras historicas: noticia da sublevação que houve em Ouro Preto em 1720. O Jornal (Rio de Janeiro), 13 e 20 out., 3, 10, 17 e 24 nov., 8 e 22 dez. 1929.

LISBOA, João Luís. Chegou paquete e pelas cartas se sabe (manuscritos cruzados). In: et al. (Orgs.). Gazetas manuscritas da Biblioteca de Évora (1735-1737). Lisboa: Colibri, 2011, p. 15-51.

Mots (dits) écrits: formes et valeurs de la diffusion des idées au 18ème siècle, au Portugal. Tese (doutorado em história e civilização), Instituto Universitário Europeu, Florença, 1998

LOPES, Francisco Antonio. Os palácios de Vila Rica: Ouro Preto no Ciclo do Ouro. Belo Horizonte: Imprensa Oficial, 1955

MACHADO, Diogo Barbosa. Bibliotheca lusitana historica, critica e cronologica. Lisboa: Ignacio Rodrigues, 1747, t. II.

MAGALHÃES, J. V. Couto de. Um episodio da historia patria (1720). Revista Trimensal do Instituto Historico Geographico e Ethnografico do Brasil (Rio de Janeiro), v. 25 , 1862, v. 25, p. 515-564.

MARCOS, David Martín; MONTEIRO, Rodrigo Bentes. Penachos de ideias: a guerra de sucessão da Espanha e a formação de Pedro Miguel de Almeida Portugal, $3^{\circ}$ conde de Assumar. Varia História (Belo Horizonte), v. 33, n. 61, jan./abr. 2017, p. 253-284.
MARQUILHAS, Rita. Em torno do Vocabulario de Bluteau: o reformismo e o prestígio da norma no século XVIII. In: MATEUS, Maria Helena Mira (Org.). Caminhos do português. Lisboa: Biblioteca Nacional, 2001, p. 105-118.

MARTINS, Maria T. Esteves Payan. A censura literária em Portugal nos séculos XVII e XVIII. Lisboa: Fundação Calouste Gulbenkian, 2005.

McKENZIE, Donald F. Bibliography \& the sociology of texts. Port Chester: Cambridge University Press, 1999.

MONTEIRO, Nuno Gonçalo (Org.). Meu pai e meu senhor muito do meu coração: correspondência do conde de Assumar para seu pai, o marquês de Alorna. Lisboa: Quetzal, 2000.

MONTEIRO, Rodrigo Bentes. Catilinária mineira: o discurso da revolta de 1720 em Vila Rica. In: ; Sandra Bagno (Orgs.). Maquiavel no Brasil: dos descobrimentos ao século XXI. Rio de Janeiro: FGV, 2015, p. 179-221.

O rei no espelho: a monarquia portuguesa e a colonização da América 1640-1720. São Paulo: Hucitec, 2002.

MOTA, Isabel Ferreira da. A Academia Real da História: os intelectuais, o poder cultural e o poder monárquico no séc. XVIII. Coimbra: Minerva, 2003.

MUHANA, Adma. A epopéia em prosa seiscentista. São Paulo: Fundação Editora Unesp, 1997.

NOGUEIRA, Arlinda Rocha et al. (Orgs.). Catálogo dos manuscritos: coleção Alberto Lamego. São Paulo: Edusp, 2002.

NORTON, Manuel Artur. D. Pedro Miguel de Almeida Portugal. Lisboa: Agência Geral do Ultramar, 1967.

OLYNTHO, Antonio. Revolta de Vila Rica de 1720. Revista do Instituto Histórico e Geográfico Brasileiro (Rio de Janeiro), t. 85, v. 139, 1921 [1919], p. 443-498.

OVÍDIO. Metamorfoses. São Paulo: Editora 34, 2017.

PALOMO, Federico. Conexiones atlánticas: Fr. Apolinário da Conceição, la erudición religiosa y el mundo del impreso en Portugal y la América portuguesa durante el siglo XVIII. Cuadernos de Historia Moderna (Madri), XIII, 2014, p. 111-137.

PEREIRA, Marcos Aurélio. Vivendo entre cafres: a trajetória do conde de Assumar e o império ultramarino português. Curitiba: Prismas, 2016.

PEREIRA, Maria Helena da Rocha. Estudos de história da cultura clássica: cultura romana. Lisboa: Fundação Calouste Gulbenkian, 2009. 
PLA, Xevi Camprubí i. L'impressor Rafael Figueró (1642-1726) i la premsa a la Catalunya del seu temps. Tese (doutorado em história), Universidade de Barcelona, Barcelona, 2013.

RED, Avelina Carrera de la (Org.). Salustio: la conjuración de Catilina. Guerra de Jugurta. Madri: Akal/Clásica, 2001.

REGOLIOSI, Mariangela. Nel cantiere del Valla: elaborazione e montaggio delle Elegantie. Roma: Bulzoni, 1993.

RODRIGUES, José Honório. História da história do Brasil: historiografia colonial. São Paulo: Companhia Editora Nacional, 1979.

ROMEIRO, Adriana. Paulistas e emboabas no coração das Minas: idéias, práticas e imaginário político no século XVIII. Belo Horizonte: Editora UFMG, 2008.

Um visionário na corte de $\mathrm{D}$. João $\mathrm{V}$ : revolta e milenarismo nas Minas Gerais. Belo Horizonte: Editora UFMG, 2001.

SILVEIRA, Marco Antonio (Orgs.). Diogo de Vasconcelos: o ofício do historiador. Belo Horizonte: Autêntica, 2014.

SILVA, Marisa Ribeiro. O artífice da memória. Revista do Arquivo Público Mineiro (Belo Horizonte), v. 43, jan.jun. 2007, p. 74-91.

SOFFIATI, Arthur. Mário de Andrade e (m) Campos dos Goytacazes: cartas de Mário de Andrade a Alberto Lamego (1935-1938). Niterói: Eduff, 1992.

SOUZA, Laura de Mello e. Desclassificados do ouro: a pobreza mineira no século XVIII. Rio de Janeiro: Graal, 1982.

(Org.). Discurso histórico e político sobre a sublevação que nas Minas houve no ano de 1720. Belo Horizonte: Fundação João Pinheiro, 1994.

. Inferno atlântico: demonologia e colonização. Séculos XVI-XVIII. São Paulo: Companhia das Letras, 1993.
Norma e conflito: aspectos da história de Minas no século XVIII. Belo Horizonte: Editora UFMG, 1999.

O diabo e a Terra de Santa Cruz: feitiçaria e religiosidade popular no Brasil colonial. São Paulo: Companhia das Letras, 1986.

O sol e a sombra: política e administração na América portuguesa do século XVIII. São Paulo: Companhia das Letras, 2006.

Opulência e miséria das Minas Gerais. São Paulo: Brasiliense, 1994.

TAUNAY, Affonso de E. História geral das bandeiras paulistas. São Paulo: Imprensa Oficial do Estado, 1949.

TORGAL, Luís Reis. Ideologia política teoria do Estado na Restauração. Coimbra: Biblioteca Geral da Universidade, 1981-1982, 2 vols.

VARNHAGEN, Francisco Adolfo de. História geral do Brasil: antes de sua separação e independência de Portugal. Belo Horizonte/São Paulo: Itatiaia/Edusp, 1981.

VASCONCELOS, Diogo de. História antiga das Minas Gerais. Belo Horizonte: Itatiaia, 1974.

VASCONCELLOS, Salomão de. Breviário histórico e turístico da cidade de Mariana. Belo Horizonte: Biblioteca Mineira de Cultura, 1947.

O palacio de Assumar: estudo critico-historico. Belo Horizonte: Queiroz Breyner, 1937.

VASCONCELLOS, Sylvio de. Mineiridade: ensaio de caracterização. Belo Horizonte: Imprensa Oficial, 1968.

Vila Rica: formação e desenvolvimento residências. São Paulo: Perspectiva, 1977.

VEIGA, José Pedro Xavier da (Org.). A revolta de 1720 em Vila Rica: discurso historico-político. Ouro Preto: Imprensa Oficial de Minas Gerais, 1898.

. Efemérides mineiras 1664-1897. Belo Horizonte: Fundação João Pinheiro, 1998, 2 vols. 